\title{
Floral attributes, ornithophily and reproductive success of Palicourea longepedunculata (Rubiaceae), a distylous shrub in southeastern Brazil
}

\author{
CELICE ALEXANDRE SILVA ${ }^{1}$, MILENE FARIA VIEIRA ${ }^{2,3}$ and CIBELE HUMMEL DO AMARAL ${ }^{2}$
}

(received: September 04, 2008; accepted: March 11, 2010)

\begin{abstract}
Floral attributes, ornithophily and reproductive success of Palicourea longepedunculata (Rubiaceae), a distylous shrub in southeastern Brazil). Floral attributes, ornithophily and reproductive success of Palicourea longepedunculata Gardner were studied in a fragment of the Atlantic Forest in southeastern Brazil. This species is a distylous shrub that occurs in wet forest understory. In an area of seven hectares, the frequency of the morphs was found at a ratio very close to the expected 1:1. The flowering period extended from March (end of the rainy season) to September, with a flowering peak in May/June (dry season). The floral attributes of the morphs were similar, i.e., the flowering of the floral morphs was synchronous, and the numbers of inflorescences per plant, flowers per inflorescence, open flowers per inflorescence and per plant of the floral morphs were similar. The pollen grains of the morphs presented similar sizes, as well as their viability. Palicourea longepedunculata is self-incompatible and mainly pollinated by Phaethornis rubber (Aves, Trochilidae), which accounted for $62.07 \%$ of the foraging bouts. The reproductive success was similar between morphs: the numbers of fruits per inflorescence were, in average, 85.7 (L-morph) and 107.1 (S-morph) and there was no significant difference in the production of seeds (one or two) per fruit between the morphs. Fruits were similar in height, width and weight.
\end{abstract}

Key words - Atlantic forest, flowering phenology, hummingbirds, Palicourea, Phaethornis

RESUMO - (Atributos florais, ornitofilia e sucesso reprodutivo de Palicourea longepedunculata (Rubiaceae), um arbusto distílico no sudeste do Brasil). Os atributos florais, a ornitofilia e o sucesso reprodutivo de Palicourea longepedunculata Gardner foram estudados em fragmento de Floresta Atlântica do sudeste do Brasil. Essa espécie é um arbusto distílico que ocorre em sub-bosque úmido de florestas. Em uma área de sete hectares, os indivíduos dos morfos brevistilo e longistilo foram encontrados em uma taxa muito próxima da esperada, 1:1. O período de floração estendeu-se de março (final da estação chuvosa) a setembro, com um pico em maio/junho (estação seca). Os atributos florais dos morfos foram similares, isto é, a floração dos morfos florais foi sincronizada e os números de inflorescências por planta, de flores por inflorescência, de flores abertas por inflorescência e por planta dos morfos foram semelhantes. Os grãos de pólen dos morfos apresentaram tamanho e viabilidade similares. Palicourea longepedunculata é autoincompatível e polinizada principalmente por Phaethornis ruber (Aves, Trochilidae), que realizou 62,07\% das ondas de forrageamento. Os morfos apresentaram sucessos reprodutivos similares: os números de frutos por inflorescência foram, em média, 85,7 (longistilo) e 107,1 (brevistilo) e não houve diferença significativa na produção de sementes (uma ou duas) por fruto entre os morfos. Os frutos foram similares em altura, largura e peso.

Palavras-chave - beija-flores, fenologia de floração, Floresta Atlântica, Palicourea, Phaethornis

\section{Introduction}

Palicourea Aublet comprises about 200 species of shrubs and small trees found throughout the moist and wet Neotropics (Taylor 1997). The flowers have tubular corolla and are odorless, brightly colored and hummingbird-pollinated (e.g. Feinsinger \& Busby 1987, Feinsinger et al. 1988, Ree 1997, Contreras \& Ornelas 1999, Coelho \& Barbosa 2003, Lau \& Bosque 2003, Ornelas et al. 2004a, b, Mendonça \& Anjos 2006, Santos

1. Universidade Estadual de Mato Grosso, Centro de Pesquisas, Estudos e Desenvolvimento Agro-Ambientais (CPEDA) câmpus de Tangará da Serra, 78300-000 Tangará da Serra, MT, Brazil.

2. Universidade Federal de Viçosa (UFV), Departamento de Biologia Vegetal, 36570-000 Viçosa, MG, Brazil.

3. Corresponding author: mfvieira@ufv.br et al. 2008). Palicourea longepedunculata Gardner is a distylous shrub found in the forest understory in southern Brazil (Taylor 1997, Pereira et al. 2006).

Distylous species are commonly self-incompatible (further details in Barret et al. 2000), thus depending on intermorph pollination through pollinators (legitimate pollination) for fruit production. The reproductive success of the long-styled (hereafter L-morph) and the short-styled (hereafter S-morph) morphs are associated to several factors: the incompatibility level of the morphs in different populations (Sobrevila et al. 1983), the distribution pattern of the morphs (Wesselingh et al. 1999) and their proportion in the population (Sobrevila et al. 1983, Pailler \& Thompson 1997) and the floral attributes (e.g. the number of inflorescences and open flowers) of each morph, which contribute to attract floral visitors (Ornelas et al. 2004b). The floral dimorphism, 
i.e., differences in the length of the corolla, style, stigma and stamen and in the pollen sizes between the morphs, common in distylous species, is another factor that may influence the reproductive success of the morphs (Lloyd 1979, Ornelas et al. 2004a, González et al. 2005).

Studies on the reproductive success of morphs of distylous Palicourea species are rare. Sobrevila et al. (1983) demonstrated that fruit and seed set of P. fendleri Standl. and P. petiolaris Kunth are highly variable among the different populations. Wesselingh et al. (1999) stated significant differences in the natural fruit set between the P. brenesii Standl. floral morphs: the S-morph fruit set were higher than in L-morph. Intermorph pollinations of P. padifolia (Willd. ex Roem. \& Schult.) C.M. Taylor \& Lorence resulted in significant difference in fruit production between floral morphs, independent of the pollination treatment and pollinator species (hummingbirds); S-morph flowers developed proportionally almost twice as many fruits as L-morph flowers (Ornelas et al. 2004a). On the other hand, González et al. (2005) observed a similar fruit production in $P$. padifolia morphs, in five years of evaluation at the same study site as Ornelas et al. (2004a).

The purpose of this study was to investigate aspects of reproductive biology of $P$. longepedunculata to answer to the questions: 1) Are the floral attributes of the morphs similar? 2) Which are the visiting hummingbirds? 3) Are the fruit and seed sets of the morphs similar?

\section{Material and methods}

Study site and species - Fieldwork was carried out in 2004 and 2005, in the forest Mata do Paraíso $\left(20^{\circ} 48^{\prime} 07^{\prime \prime} \mathrm{S}\right.$ and $\left.42^{\circ} 51^{\prime} 31^{\prime} \mathrm{W}, 680 \mathrm{~m} \Phi \mathrm{l}\right)$, a preservation area located in the municipality of Viçosa, Minas Gerais, Brazil. In the 19th century, after deforestation, the Mata do Paraíso was replaced by coffee plantations and pastures. Nowadays, a secondary succession forest (Castro 1980) covers an area of 194.36 ha, where $P$. longepedunculata grows in the shaded areas. The natural vegetation of Mata do Paraíso is part of the Atlantic Forest region (Rizzini 1992), in which the climate is characterized by a dry and cool (April to September) followed by a rainy and hot season (October to March). The annual average rainfall in this area varies from 1.300 to $1.400 \mathrm{~mm}$, and the annual average temperature is $19^{\circ} \mathrm{C}$.

Palicourea longepedunculata has elongate and pendulous inflorescences; the central axis and branches are red with yellow-reddish flowers (figure 1). The anthesis lasts 24 hours (Pereira et al. 2006). The carnose and purple fruits are dispersed by birds (Tachyphonus coronatus Vieillot, 1822) and have one or two seeds. In the Mata do Paraíso, the style and stamen length of $P$. longepedunculata differ in S-morph and L-morph flowers and are reciprocally positioned; there

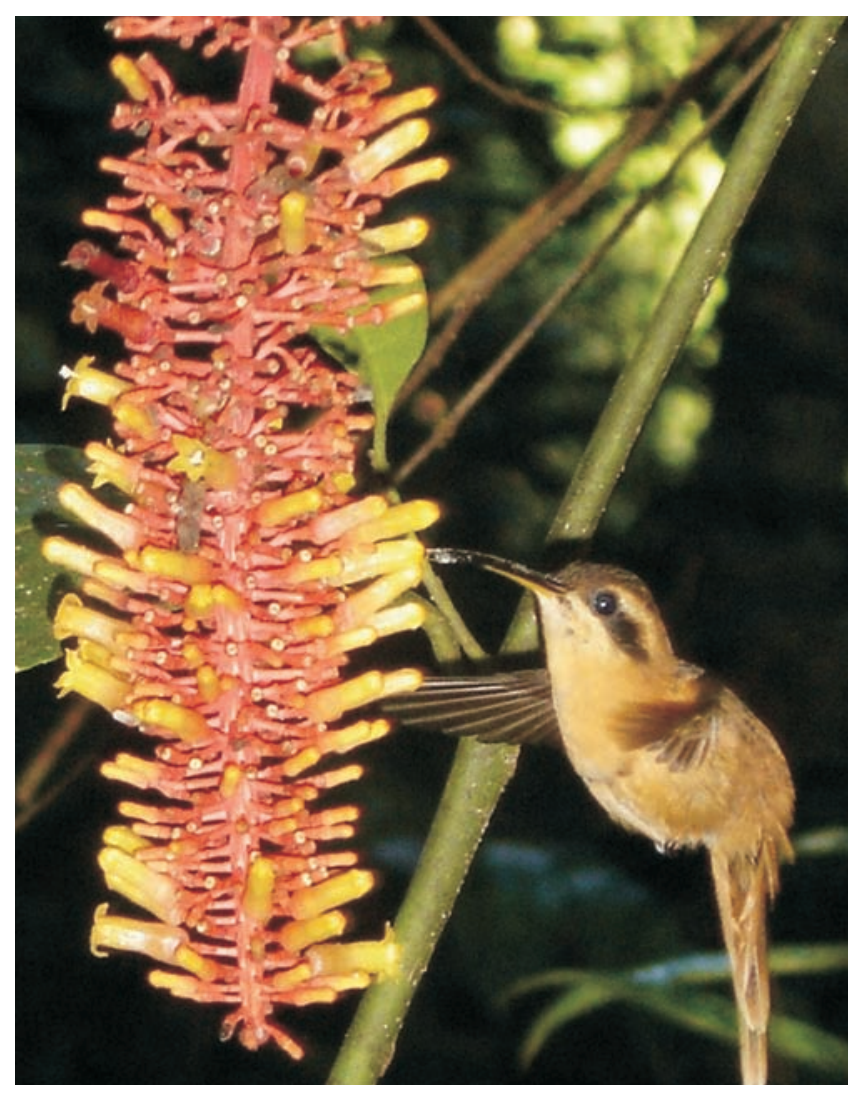

Figure 1. Phaethornis ruber visiting an inflorescence of Palicourea longepedunculata, in a forest fragment in Viçosa, Minas Gerais State, southeastern Brazil. Note pollen (white spot) in the distal region of the bill.

are significant differences in the length of the corolla and stigma between the floral morphs (longer in the S-morph); and incompatibility reaction after illegitimate in vitro pollinations (Pereira et al. 2006). Voucher specimen is deposited in the VIC herbarium (Pereira \& Basílio 61)

Frequency of morphs and floral attributes - All individuals present in an area of seven hectares were sampled and classified as S-morph or L-morph. The floral attributes: the number of inflorescences per plant, number of open flowers per inflorescence and number of open flowers per plant in 22 S-morph and $17 \mathrm{~L}$-morph plants were weekly monitored during the flowering season in 2004, and 10 plants per morph in 2005. Besides, the number of flowers produced in 24 inflorescences was counted; three inflorescences of four plants per morph were used. To verify differences between the inflorescence lengths, one inflorescence of 10 plants per morph was measured (from the first to the last flowers).

To verify pollen grain viability, five buds per plant in pre-anthesis were collected from five plants in each morph. The anthers of each bud were macerated in a drop of acetic carmine on a slide (Radford et al. 1974). Up to 200 grains per slide were counted. The diameter of pollen grains of the floral morphs was measured. Five buds per plant in pre-anthesis 
of five plants of each morph were used for this purpose. The anthers of each bud were macerated in a drop of acetic carmine on a slide (Radford et al. 1974). Images of eight grains per slides (200 grains per morph) were captured using a Olympus AX70 microscope with a 40X lens, zoom 1.0. Measures were obtained using Image-Pro Plus software.

Breeding system - Controlled pollinations were performed in vivo (details in Bawa \& Beach 1983), with a total of 80 flowers: 11 flowers for $\mathrm{S} \times \mathrm{S}$ (self-pollination), 20 for $\mathrm{S} \times \mathrm{S}$ (intramorph), 14 for $\mathrm{L} \times \mathrm{L}$ (self), 14 for $\mathrm{L} \times \mathrm{L}$ (intramorph), 07 for $\mathrm{S} \times \mathrm{L}$ (intermorph) and 14 for $\mathrm{L} \times \mathrm{S}$ (intermorph). To evaluate the fruit set under natural conditions, 12 inflorescences per morph were used as control. In this case, the fruits produced per inflorescence were counted and the percentage of fruit set calculated considering the mean number of flowers per inflorescence per morph.

To test the possibility that seedless fruits (see results) are a result of interspecific pollination, 13 L-morph and nine S-morph flowers in pre-anthesis were protected with bags. In the anthesis, they were pollinated with pollen of the ornithophilous Geissomeria schottiana Nees (Acanthaceae). Five flowers per morph were collected 24 hours after pollination and analyzed by fluorescence microscopy to verify pollen tube growth. For this purpose, the pistils were stained with aniline blue (Martin 1959). The other flowers were observed until abortion or fruit set. Geissomeria schottiana was chosen because the flowering period is synchronous with $P$. longepedunculata, it also inhabits the forest understory of the study area and both are visited by four common hummingbird species (Abreu \& Vieira 2004, this study).

Pollinators - In 2004, hummingbirds were identified in binocular observation and photographic documentation. Sites of pollen deposition on the bird were noted. In 2005, at the flowering peak (see results), on June 8, 9 and 11, from 7h00 to $12 \mathrm{~h} 00$ or from $14 \mathrm{~h} 00$ to $18 \mathrm{~h} 00$ (a total of 11 hours), the number of foraging bouts, the number of flowers visited per foraging bout and the interval between the foraging bouts of each flower visitor were recorded. All these counts were made in a place with four $P$. longepedunculata plants. The choice of the place was based on the ease of observation of the flowers and hummingbirds.

Reproductive success - The reproductive success, as suggested by Dafni et al. (2005), was measured by the count of the numbers of fruits and of seed per fruit produced in 10 inflorescences per morph. The height and width of mature and fresh fruits ( $n=30$ per morph) was measured by a digital caliper (approximate precision of $0.01 \mathrm{~mm}$ ). The fresh fruits ( $n=24$ per morph) were weighed on analytical scales (precision of $0.01 \mathrm{~g}$ ).

Data analysis - To meet parametric analysis assumptions, pollen grains viability and diameter data were square root or arcsine transformed as required (Zar 1999). All statistical analyses for floral attributes were run using general linear modeling with software Statistica (StatSoft 2002).

\section{Results}

Frequency of morphs and floral attributes - In this study 32 S-morph and 27 L-morph plants were counted, which is very close to the expected $1: 1$ ratio, and the variation in morph frequency was not significant $\left(\chi^{2}=0.51, P=0.91\right)$. In 2004, the flowering period lasted from March to August and in 2005, from April to September (figure 2 ), both in the dry season. Flowering was synchronous in the floral morphs (figure 2). There was no difference between the number of flowers per inflorescence in S-morph (in average, $407.5 \pm 232.24$ ) and L-morph (in average, $381.9 \pm 142.32)(F=0.10, P=0.75)$ plants, as well as between the number of inflorescences per plant and open flowers per inflorescence (table 1). Only in 2004, the number of open flowers per plant was higher in L-morph (table 1). It is worth highlighting that S-morph flowers were significantly longer $(\mathrm{mm})$ than L-morph (respectively, $11.75 \pm 1.23$ and $8.27 \pm 0.79, P<0.01$; Pereira et al. 2006), but the L-morph inflorescences were significantly longer $(\mathrm{cm})$ than S-morph (in average, respectively, $15.8 \pm 4.73$ and $9.6 \pm 9.68, P=0.017$ ). All data indicate that the flower attributes of the morphs are largely similar.

The pollen grains of the morphs are similar in morphology as well as viability (table 2). In $11 \mathrm{~S}$-morph and five L-morph flowers it was not possible to count the 200 grains per slide. The anthers were partially dehydrated and the number of pollen grains reduced (range from 0 to 110).

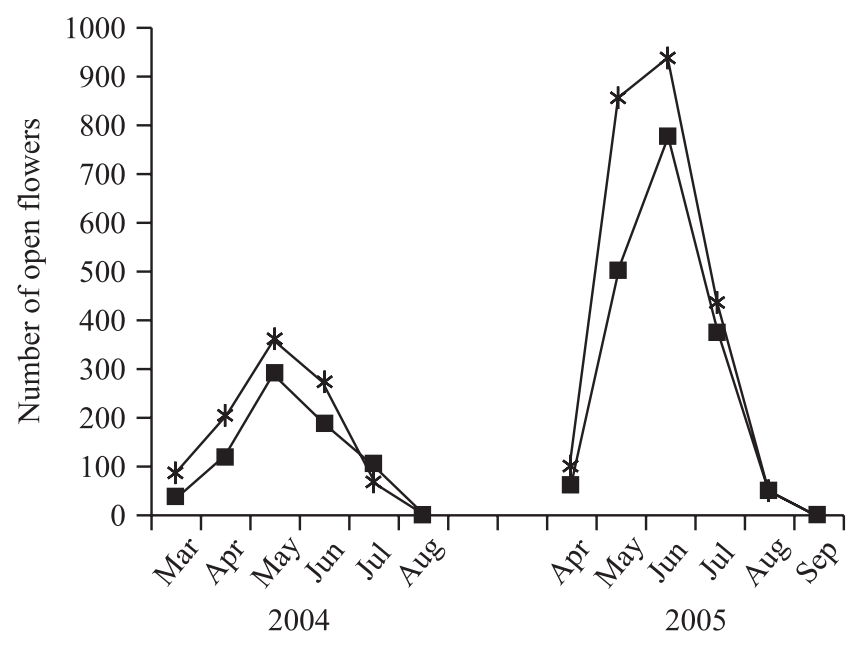

Figure 2. Flowering period of the floral morphs of Palicourea longepedunculata, in a forest fragment in Viçosa, Minas Gerais State, southeastern Brazil, in 2004 and 2005. ( $\mathbf{\square}=$ S-morph; * = L-morph). 
Table 1. Mean numbers of inflorescences per plant, of open flowers per inflorescence and of open flowers per plant of the floral morphs of Palicourea longepedunculata, in a forest fragment in Viçosa, Minas Gerais State, southeastern Brazil.

\begin{tabular}{|c|c|c|c|c|c|c|}
\hline \multirow{2}{*}{$\begin{array}{c}\text { Year/ Morph } \\
\text { (number of plants) }\end{array}$} & \multicolumn{2}{|c|}{ Inflorescences per plant } & \multicolumn{2}{|c|}{ Open flowers per inflorescence } & \multicolumn{2}{|c|}{ Open flowers per plant } \\
\hline & $\bar{X} \pm S$ & $P$ & $\bar{X} \pm S$ & $P$ & $\bar{X} \pm S$ & $P$ \\
\hline \multicolumn{7}{|l|}{ 2004/ } \\
\hline S-morph (22) & $09.93 \pm 08.04$ & & $19.85 \pm 28.96$ & & $33.31 \pm 30.80$ & \\
\hline L-morph (17) & $09.18 \pm 06.44$ & 0.33 & $25.97 \pm 15.22$ & 0.38 & $58.05 \pm 23.55$ & $0.009 *$ \\
\hline \multicolumn{7}{|l|}{ 2005/ } \\
\hline S-morph (10) & $12.90 \pm 12.60$ & & $11.70 \pm 03.08$ & & $177.10 \pm 230.12$ & \\
\hline L-morph (10) & $07.90 \pm 04.74$ & 0.26 & $15.80 \pm 04.15$ & 0.93 & $255.20 \pm 171.42$ & 0.400 \\
\hline
\end{tabular}

* significant at $1 \%$ probability.

Table 2. Mean diameter and viability of pollen grains and mean width, height and weight of fruits of floral morphs of Palicourea longepedunculata, in a forest fragment in Viçosa, Minas Gerais State, southeastern Brazil.

\begin{tabular}{|c|c|c|c|}
\hline \multirow{3}{*}{ Attribute } & \multicolumn{3}{|c|}{ Morph } \\
\hline & \multirow{2}{*}{$\begin{array}{c}\text { S-morph } \\
\bar{X} \pm S\end{array}$} & \multicolumn{2}{|c|}{ L-morph } \\
\hline & & $\bar{X} \pm S$ & $P$ \\
\hline \multicolumn{4}{|l|}{ Pollen } \\
\hline Diameter $(\mu \mathrm{m})$ & $9.27 \pm 0.25$ & $8.83 \pm 0.21$ & 0.16 \\
\hline Viability (\%) & $79.40 \pm 30.65$ & $86.78 \pm 30.65$ & 1.81 \\
\hline \multicolumn{4}{|l|}{ Fruit } \\
\hline Width (mm) & $0.77 \pm 0.06$ & $0.77 \pm 0.01$ & 0.66 \\
\hline Height (mm) & $0.73 \pm 0.04$ & $0.72 \pm 0.09$ & 0.62 \\
\hline Weight (g) & $0.117 \pm 0.046$ & $0.113 \pm 0.031$ & 0.58 \\
\hline
\end{tabular}

Breeding system - No fruits were produced by selfing and intramorph pollinations. Intermorph pollinations accounted for $57.1 \%$ (S-morph $\times$ L-morph) and 78.6\% (L-morph $\times \mathrm{S}$-morph) of fruit set. These results showed that $P$. longepedunculata is self-incompatible, confirming the results of Pereira et al. (2006). In average, there was no difference between the fruit sets of the control ( $F=0.52, P=0.48$ ), which was $26.3 \%$ in S-morph and $22.4 \%$ in L-morph flowers.

In the flowers pollinated with pollen grains of $G$. schottiana the pollen tubes grew to the style base and there was no fruit production.

Pollinators - Four hummingbird (Aves, Trochilidae) species were recorded (table 3) visiting various open flowers per plant, all day long. A fifth hummingbird, Amazilia fimbriata (Gmelin, 1788), was observed only towards the end of the flowering period 2004. The visits were single, i.e., one hummingbird species per foraging bout. Pollen was deposited in the distal region of the hummingbird's bill (figure 1).

Phaethornis ruber (Linnaeus, 1758) (figure 1) was the main pollinator, observed in 18 of the 29 foraging bouts recorded (table 3 ). These foraging bouts were repeated every 15 to 50 minutes, when the hummingbirds performed from one to 60 visits. In the afternoon of June 8, 232 visits were counted in six foraging bouts; in the morning of June 11, 273 visits were counted in 12 foraging bouts. Phaethornis ruber performed 79\% and $95 \%$ of these visits, respectively.

Reproductive success - Both fruit and seed set were similar in the morphs (table 4). The fruits were also similar in height, width and weight (table 2).

Seedless fruits were observed, which developed until half the size of fruits with seeds; at this point, they dropped. The percentage of seedless fruits was significantly higher in L-morph flowers (table 4). 
Table 3. Hummingbird species, bill length and visitation frequency ( $n=29$ foraging bouts) of flowers of Palicourea longepedunculata, in a forest fragment in Viçosa, Minas Gerais State, southeastern Brazil.

\begin{tabular}{llcc}
\hline Subfamily/Species & Common name & $\begin{array}{c}\text { Bill length* } \\
\text { (cm) }\end{array}$ & $\begin{array}{c}\text { Frequency } \\
\text { (\%) }\end{array}$ \\
\hline Phaethornithinae/ & & & \\
$\quad$ Phaethornis ruber (Linnaeus, 1758) & Reddish Hermit & 2.2 & 62.07 \\
P. squalidus (Temminck, 1822) & Dusky-throated Hermit & 2.4 & 17.24 \\
Trochilinae/ & & & \\
$\quad$ Chlorostilbon lucidus (Shaw, 1812) & Glittering-bellied Emerald & 1.4 & 6.89 \\
$\quad$ Thalurania glaucopis (Gmelin, 1788) & Violet-capped Woodnymph & 1.7 & 13.79 \\
\hline
\end{tabular}

* According to Ruschi (1982).

Table 4. Total number of fruits and seeds produced in 10 inflorescences of floral morphs of Palicourea longepedunculata, mean number of fruits per inflorescence and percentage of fruits with 0, 1 or 2 seeds, in a forest fragment in Viçosa, Minas Gerais State, southeastern Brazil.

\begin{tabular}{lcccccc}
\hline \multirow{2}{*}{ Morph } & Total fruits - seeds & Fruits per inflorescence & & \multicolumn{3}{c}{ Seeds per fruit (\%) } \\
\cline { 3 - 3 } \cline { 5 - 7 } & & $\bar{X} \pm S$ & & 0 & 1 & 2 \\
\hline S-morph & $1071-1809$ & $107.1 \pm 46.47$ & & 05.06 & 21.00 & 73.94 \\
L-morph & $857-1210$ & $85.7 \pm 47.34$ & & 16.90 & 25.00 & 58.10 \\
$F$ & & 1.04 & & 40.32 & 2.40 & 0.43 \\
$P$ & & 0.320 & & $0.007^{*}$ & 0.200 & 0.880 \\
\hline
\end{tabular}

* Significant at $1 \%$ probability.

\section{Discussion}

The similarity of floral attributes in the $P$. longepedunculata morphs was favored by the equilibrium morph ratio and flowering synchrony, and suggests similar allocation to pollinator attraction and pollen dispersal. González et al. (2005) verified that L-morph plants of Palicourea padifolia initiated more floral buds per inflorescence than S-morph, suggesting a strong relation with pollinator attraction and, potentially, an increase in male fitness through pollen donation; although fruit set was similar between morphs. The floral morphs of several distylous species specialize in their reproductive effort through male and female function (Lloyd 1979). The similar reproductive performance of the $P$. longepedunculata morphs suggests the participation of both as pollen donor and recipient in the population. However, S-morph plants tended to produce more fruits and seeds and therefore, more samplings over a longer period is needed to detect gender specialization, as proposed by González et al. (2005).

The flowering strategy of $P$. longepedunculata seems to be efficient to attract hummingbirds, mainly
Phaethornis ruber, in view of its high frequency and constancy of visitation. Vieira et al. (2007) observed a similar strategy in the ornithophilous Corymborkis flava (Sw.) Kuntze, a terrestrial orchid of the forest understory in the same study area. This orchid produces abundant bright yellow flowers per plant and day and this abundance of flowers seems to maintain the constancy of hummingbird visitation.

The short corolla tubes of the $P$. longepedunculata permit the visitation of hummingbird species with different bill dimensions ( $c f$. Johnson \& Edwards 2000, Consolaro et al. 2005). In fact, in a Neotropical community, species with long corolla are associated with a lower diversity of hummingbird pollinators, compared to species with shorter corolla (Wolf et al. 1976).

Despite the diversity of hummingbirds observed in Palicourea longepedunculata, Phaethornis ruber stood out as the main pollinator. Abreu \& Vieira (2004) also observed the predominance of the visits of one hummingbird species over the four other observed in the ornithophilous Geissomeria schottiana, in the same study area. These authors demonstrated that Thalurania glaucopis (Gmelin, 1788) accounted for $64.8 \%$ of the 
visitation in about 15 hours of observation. Geissomeria schottiana, as well as $P$. longepedunculata, flowers abundantly during the dry season (Abreu \& Vieira 2004). These results indicate the existence of an organization of the hummingbird community for an efficient use of the nectar produced by the plant community ( $c f$. Wolf et al. 1976). However, studies on different aspects of the birds and plants in the community are needed, for a more in-depth analysis.

The other hummingbirds, due to the low frequency of visitation, may be considered sporadic pollinators of Palicourea longepedunculata. Among these, Phaethornis squalidus and P. ruber are trapliners (Janzen 1971, Stiles 1975), favoring cross pollination (cf. Stiles 1975). However, these hummingbirds visited several flowers per plant in the same foraging bout, a behavior that favors geitonogamous pollinations and may result in stigma clogging by the deposition of incompatible pollen grains, resulting in low fruit set. For example, in the distylous Turnera ulmifolia L. (Turneraceae), due to the occlusion of stigmas, the fruit set of L-morph tended to be lower than that of S-morph flowers (Shore \& Barret 1984). Although stigma clogging was out of the scope of this paper, the results indicate that $P$. longepedunculata morphs may be equally affected by the deposition of incompatible pollen, considering their similar natural fruit set. Higher natural fruit set were observed in other distylous Palicourea species (see Sobrevila et al. 1983, Ree 1997, Wesselingh et al. 1999), aside from P. salicifolia (15\% for both flower morphs together; Wesselingh et al. 1999). The percentages of natural fruit set of $P$. longepedunculata were apparently low due to the high number of flowers (> 381) per inflorescence. However, do not result in a low fruit ( $>85$ per inflorescence) and seed production, as shown in the results.

The likeness of both fruit morphology and set between the $P$. longepedunculata morphs suggests similar allocation to dispersor attraction. Thus, the morphs have the same chances of establishing new plants in the population, resulting in a balanced ratio of the morphs, as verified here. Higher natural fruit set with two seeds corroborated the effectiveness of the hummingbirds, in particular of Phaethornis ruber, as pollinator. Feinsinger et al. (1988) stated the necessity of at least two pollen tubes for full seed set (also two seeds) in Palicourea lasiorrachis.

The seedless fruits production, as verified in $P$. longepedunculata, was not a result of the stimulus triggered by the intramorph or interspecific pollinations. Feinsinger et al. (1988) also verified seedless fruit production in P. lasiorrachis. Future studies may address this issue in these species.

Summing up, this study showed similarities in the floral attributes and reproductive success between the floral morphs of the ornithophilous $P$. longepedunculata, which are poorly investigated aspects in research on the reproductive biology of distylous species of Rubiaceae.

Acknowledgements - The authors wish to thank the CNPq (National Council of Scientific and Technological Development) for a scholarship of Undergraduate Students' Research Program of the third author and for the award for Excellence in Research of the second author; they also gratefully acknowledge the help of Geraldo T. de Mattos with the identification of the hummingbirds and the administration of the Mata do Paraíso for allowing the field work.

\section{References}

ABREU, C.R.M. \& VIEIRA, M.F. 2004. Os beija-flores e seus recursos florais em um fragmento florestal de Viçosa, sudeste brasileiro. Lundiana 5:129-134.

BARRET, S.C.H., JESSON, L.K. \& BAKER, A.M. 2000. The evolution and function of stylar polymorphisms in flowering plants. Annals of Botany 85:253-265 (supplement).

BAWA, K.S. \& BEACH, J.H. 1983. Self- incompatibility systems in the Rubiaceae of a tropical lowland wet forest. American Journal of Botany 70:1281-1288.

CASTRO, P.S. 1980. Influência da cobertura florestal na qualidade da água em duas bacias hidrográficas na região de Viçosa, MG. Tese de mestrado, Thesis, Escola Superior de Agricultura Luiz de Queiroz, Piracicaba.

COELHO, C.P. \& BARBOSA, A.A. 2003. Biologia reprodutiva de Palicourea macrobotrys Ruiz \& Pavon (Rubiaceae): um possível caso de homostilia no gênero Palicourea Aubl. Revista Brasileira de Botânica 26: 403-413.

CONSOLARO, H., SILVA, E.B. \& OLIVEIRA, P.E. 2005. Variação floral e biologia reprodutiva de Manettia cordifolia Mart. (Rubiaceae). Revista Brasileira de Botânica 28:85-94.

CONTRERAS, P.S. \& ORNELAS, J.F. 1999. Reproductive conflicts of Palicourea padifolia (Rubiaceae) a distylous shrub of a Tropical cloud forest in Mexico. Plant Systematics and Evolution 219:225-241.

DAFNI, A., KEVAN, P.G. \& HUSBAND, B.C. 2005. Practical pollination biology. Cambridge University Press, Cambridge.

FEINSINGER, P. \& BUSBY, W.H. 1987. Pollen carryover: experimental comparisons between morphs of Palicourea lasiorrachis (Rubiaceae), a distylous, bird-pollinated, tropical treelet. Oecologia 73:231-235. 
FEINSINGER, P., BUSBY, W.H. \& TIEBOUT, H.M. 1988. Effects of indiscriminate foraging by tropical hummingbirds on pollination and plant reproductive success: experiments with two tropical treelets (Rubiaceae). Oecologia 76:471-474.

GONZÁLEZ, C., ORNELAS, J.F. \& JIMÉNEZ, L. 2005. Between-year changes in functional gender expression of Palicourea padifolia (Rubiaceae), a distylous, and hummingbird-pollinated shrub. Annals of Botany 95:371-378.

JANZEN, D.H. 1971. Euglossine bees as long-distance pollinators. Science 171:203-205.

JOHNSON, S.D. \& EDWARDS, T.J. 2000. The structure and function of orchid pollinaria. Plant Systematics and Evolution 222:243-269.

LAU, P. \& BOSQUE, C. 2003. Pollen flow in the distylous Palicourea fendleri (Rubiaceae): an experimental test of the disassortative pollen flow hypothesis. Oecologia 135:593-600.

LLOYD, D.G. 1979. Evolution toward dioecy in heterostylous population. Plant Systematics and Evolution 131:71-80.

MARTIN, F.M. 1959. Staining and observing pollen tubes in style by means of fluorescence. Stain Technology 34:436-437.

MENDONÇA, L.B. \& ANJOS, L. 2006. Flower morphology, nectar features, and hummingbird visitation to Palicourea crocea (Rubiaceae) in the Upper Paraná River floodplain, Brazil. Anais da Academia Brasileira de Ciências 78:45-57.

ORNELAS, J.F., JIMÉNES, L., GONZÁLEZ, C. \& HERNÁNDEZ, A. 2004a. Reproductive ecology of distylous Palicourea padifolia (Rubiaceae) in a tropical montane cloud forest. I. Hummingbirds' effectiveness as pollen vectors. American Journal of Botany 91: 1052-1060.

ORNELAS, J.F., GONZÁLEZ, C., JIMÉNEZ, L., LARA, C. \& MARTÍNEZ, A.J. 2004b. Reproductive biology of distylous Palicourea padifolia (Rubiaceae) in a tropical montane cloud forest, II Attracting and rewarding mutualistic and antagonistic visitors. American Journal of Botany 91:1061-1069.

PAILLER, T. \& THOMPSON, J.D. 1997. Distyly and variation in heteromorphic incompatibility in Gaertnera vaginata (Rubiaceae) endemic to La Reunion Island. American Journal of Botany 84:315-327.

PEREIRA, Z.V., VIEIRA, M.F. \& CARVALHO-OKANO, R.M. 2006. Fenologia de floração, morfologia floral e sistema de incompatibilidade em espécies distílicas de Rubiaceae em fragmento florestal do sudeste brasileiro. Revista Brasileira de Botânica 29:471-480.
RADFORD, A.E., DICKSON, W.C., MASSEY, J.R. \& BELL, C.R. 1974. Vascular plant systematics. Harper \& Row, New York.

REE, R. 1997. Pollen flow, fecundity, and the adaptive significance of heterostyly in Palicourea padifolia (Rubiaceae). Biotropica 29:298-308.

RIZZINI, C.T. 1992. Tratado de fitogeografia do Brasil: aspectos ecológicos, sociológicos e florísticos. Âmbito Cultural, São Paulo.

RUSCHI, A. 1982. Aves do Brasil - Beija-flores do Brasil. Editora Rios, São Paulo.

SANTOS, O.A., WEBBER, A.C. \& COSTA, F.R.C. 2008. Biologia reprodutiva de Psychotria spectabilis Steyrm. e Palicourea cf. virens (Poepp \& Endl.) Standl. (Rubiaceae) em uma floresta tropical úmida na região de Manaus, AM, Brasil. Acta Botânica Brasilica 22:275-285.

SHORE, J.S. \& BARRET, S.C.H. 1984. The effect of pollination intensity and incompatible pollen on seed set in Turnera ulmifolia (Turneraceae). Canadian Journal of Botany 62:1298-1303.

SOBREVILA, C., RAMIREZ, N. \& ENRECH, N.X. DE. 1983. Reproductive biology of Palicourea fendleri e $P$. petiolaris (Rubiaceae), heterostylous shrubs of a tropical cloud forest in Venezuela. Biotropica 15:161-169.

STATSOFT INC. 2002. Statistica for Windows (Computer Program Manual). StatSoft Inc., Tulsa.

STILES, F.G. 1975. Ecology, flowering phenology, and hummingbird pollination of some Costa Rica Heliconia species. Ecology 56:285-301.

TAYLOR, C.M. 1997. Conspectus of the genus Palicourea (Rubiaceae: Psychotrieae) with the description of some new species from Ecuador and Colombia. Annals of the Missouri Botanical Garden 84:224-262.

VIEIRA, M.F., ANDRADE, M.R.S., BITTENCOURT JR, N.S. \& CARVALHO-OKANO, R.M. 2007. Flowering phenology, nectar structure and breeding system in Corymborkis flava (Spiranthoideae:Tropidieae), a terrestrial orchid from a Neotropical forest. Australian Journal of Botany 55:635-642.

WESSELINGH, R.A., WITTEVELDT, M., MORISSETTE, J. \& DEN NIJS, H.C.M. 1999. Reproductive ecology of understory species in a tropical montane forest in Costa Rica. Biotropica 31:637-645.

WOLF, L.L., STILES, F.G. \& HAINSWORTH, F.R. 1976. Ecological organization of a tropical, highland hummingbird community. Journal of Animal Ecology 45:349-379.

ZAR, J.H. 1999. Biostatistical analysis. 4th ed. Prentice-Hall, Upper Saddle River. 